\title{
Thucydides and Democratic Peace
}

\author{
Eric Robinson
}

Associate Professor, Department of History, 742 Ballantine Hall, Indiana

University, Bloomington, IN 47405-7103, United States, Tel: +1 212-855 1745, ewr@indiana.edu

Thucydides is an important author for any discussion of the possibilities for an ancient Greek democratic peace. Though democratic peace did not, in fact, seem to function in classical Greece, a number of passages in Thucydides show that an affinity did exist among democratic factions and city-states in the context of hostile competition between democratic and oligarchic regimes. Thucydides remarked on this competition and was aware of the inter-democratic affinities, but did not seem to think them salient in city-state decisions of war and peace. The failure of democratic peace to develop may relate to the environment of the Greek city-state, which privileged local interests over broader constitutional ideals.

KEY WORDS: democracy, polis, democratic peace, liberal peace, Thucydides, oligarchy, ancient Greece, constitutions, Peloponnesian War

\section{INTRODUCTION}

Democratic peace - the hypothesis that democracies never, or very rarely, go to war with one another - could not be more relevant to international affairs than they seem to be at present. An obvious sign of this is the increasing stridency with which the President of the United States has pushed the notion that liberal governments bring peace, and that American security and freedom depends upon spreading democracy around the world. While critics might note that President Bush's policies seem to feature going to war to achieve this peace, it is nevertheless significant that the President frequently voices the expectation that more democracies will result in a 
safer, more peaceful world. The ongoing, difficult democratization efforts in occupied Iraq surely provide some of the impetus behind this increasingly insistent rhetoric, but the idea first appears prominently in the White House's National Security Strategy statement of 2002. ${ }^{1}$ It then recurs in many subsequent presidential speeches, including the State of the Union address of 2004, and most dramatically in the Inaugural Address of 2005, in which the President made the expansion of liberty and the ending of tyrannies everywhere America's primary mission in the world - indeed, he labeled it the 'calling of our time.' Similar statements have abounded in the year since. At President Bush's press conference of January 26, 2005, for example, he stated that 'Free societies are peaceful societies' and '...Freedom is necessary in order to promote peace.' It seems that the ideology of democratic peace — at least one version of it - has found a vocal supporter in the current White House. ${ }^{2}$

But skepticism about the likely success of President Bush's policy and the very notion of democratic peace as he would apply it is not hard to find, ${ }^{3}$ and drives one to ask how well-founded in history the supposed phenomenon might be. How far back can one demonstrate the existence of democratic peace? A few years ago I published an article in the Journal for Peace Research (Robinson, 2001a) challenging the arguments by a few scholars who allege that democratic peace operated not only in the modern world but in classical Greece as well, which would add quite an impressive pedigree. I was moved to write the article because my research on classical Greek democracy suggested to me that significant problems would face anyone claiming that it operated in antiquity. The case for a modern democratic peace (also called liberal peace) seemed rather strong empirically, in contrast with that for any ancient Greek version. ${ }^{4}$ Thus my article went about trying to address the claims for 
the ancient version. The point was not to say that democratic peace as a general theory was wrong, but merely that it did not seem to apply to the ancient world.

The present paper will revisit this issue and attempt to discover why democratic peace did not function by focusing on Thucydides, the subject of this special issue and the PRIO conference from which it stems. Thucydides is a central author in the argument about a Greek democratic peace, and it will be illuminating to probe a little farther than did my earlier article into his understanding of and reports about wars, alliances, and popular governments in his time. (I will not attempt, as does Russett in this issue, a more generalized look at factors potentially inhibiting an ancient democratic peace.) One finds a curious tension in Thucydides when trying to apply the notion of democratic peace to his writing: on the one hand, as the spiritual father of the realist school of international affairs, ${ }^{5}$ his outlook does not readily accommodate the retrojection of the rather idealist notion of democratic peace; on the other hand, evidence in his history can indeed be found for a cooperative relationship of some kind between democratic factions and polities. Sorting out how and why this cooperative relationship existed without democratic peace itself emerging is the goal of this paper.

\section{THE ABSENCE OF AN ANCIENT DEMOCRATIC PEACE}

To summarize briefly the argument made in my previous article, it started by contending that the ancient world is an entirely appropriate era to investigate with regard to the issue given the striking similarity of democratic ideals ancient and modern. In both eras the same two principles, freedom and equality, are touted as the supreme principles of a democratic state. For example, democracies ancient and 
modern place great value on collective freedom from domination by an oppressive ruler or ruling class, individual freedom to live as one wishes, and equal treatment of citizens before the law. Of course, the manner of implementation of these ideals and the social contexts in which they flourish vary dramatically (as they must any time one compares political arrangements in distant historical eras). As we will see later in this paper, the variation in context — especially the Greek city-state (polis) setting may offer a possible explanation for the main conclusion of my earlier study, which was that democratic peace does not seem to have obtained in classical Greece. Contrary to what investigators Bruce Russett \& William Antholis (1992, 1993) and Spencer Weart (1998) had hoped to show, the evidence from the period in and around the Peloponnesian War indicates that not only did ancient democracies go to war with each other, they did so with a fair frequency. Both quantitative and traditional literary analyses supported this conclusion. The most famous and perhaps most telling case was that of the Athenian expedition to Sicily in $415 \mathrm{BC}$, a campaign on which Thucydides lavishes a great deal of attention in his history. Here we find one democracy, Athens, launching an unprovoked assault on another, Syracuse, with control of Greek Sicily hanging in the balance. Weart's attempt to deny the label democracy (Greek demokratia) to Syracuse fails to convince, coming across as a desperate ploy to save his notion that wars never occurred among ancient democratic states. I also advanced several other cases not raised by other investigators of wars among democratic states in the fifth century BC, further undermining the case for an ancient democratic peace and contributing to my conclusion that insufficient evidence exists to argue credibly for the phenomenon in the ancient world. ${ }^{6}$

\section{THUCYDIDES AND DEMOCRATIC AFFINITIES}


Nevertheless, one must admit that there are some intriguing statements in the ancient sources that indicate the formation of a special relationship between Greek democracies (and democratic factions) of the fifth and fourth centuries BC. Russett \& Antholis $(1992,1993)$ point out some of these passages in their studies, and there are several others one should bring into the discussion as well. Thucydides, as it turns out, authored many of them. In fact, his history reveals much about the connections that existed between ancient democracies.

Relatively early in his history Thucydides makes a fundamental claim about the relationship between the Peloponnesian War and the competition between democrats and oligarchs taking place in city-states (poleis) throughout Greece. After having described the initial stages of a bloody civil war in Corcyra between democrats favoring alliance with Athens and oligarchs preferring ties with Corinth and Sparta, he states (3.82.1):

...[The revolution] seemed the more savage, because it was among the first that occurred; for afterwards practically the whole Hellenic world was convulsed, since in each state the leaders of the democratic faction (hoi tōn demōn prostatai) were at variance with the oligarchs (hoi oligoi), the former seeking to bring in the Athenians, the latter the Spartans. And while in time of peace they would have had no pretext for asking their intervention, nor any inclination to do so, yet now that these two states were at war, either faction in the various cities, if it desired a revolution, found it easy to 
bring in allies also, for the distress at one stroke of its opponents and the strengthening of its own cause.

And, a little later in the same section, 3.82.8:

The cause of all these evils was the desire to rule which greed and ambition inspire, and also, springing from them, that ardor which belongs to men who once have become engaged in factious rivalry. For those who emerged as party leaders in the several cities, by assuming on either side a fair-sounding name, the one using as its catch-word 'political equality for the masses' (plèthous isonomias politikēs) the other 'prudent aristocracy' (aristokratias sōphronos) while they pretended to be devoted to the common weal, in reality made it their prize. ${ }^{7}$

Thucydides in this section has been describing the traumatic civil strife at Corcyra with more horrified passion and greater detail than he devotes to any other such conflict covered in his history; clearly, he intends the account to stand as a searing example of the nature of this kind of struggle, one that he states (here and elsewhere) was cropping up all across Greece during the course of the long Peloponnesian War. For our purposes, we must note the assertion that, in general, democratic factions sought to bring in Athenian aid, and oligarchic ones Spartan aid. This assertion fits well with claims made in various classical authors that Athens tended to support democracies and Sparta oligarchies, ${ }^{8}$ and establishes a clear affinity between democratic Athens and factions fighting for democratic government in their own 
states. But two wrinkles must also be noted: Thucydides emphasizes the effect of the larger war between Athens and Sparta in triggering this sort of partisan conflict and competitive intervention by greater powers: without it, leaders would not have the excuse (or even the desire?) to call for aid. He also stresses the small-minded motives of the various factional leaders, however grand their slogans may sound. We will return to these points later.

Another potentially revealing passage in Thucydides comes as he describes the debate in Athens over what to do with the surrendered population of Mytilene after the violent rebellion of that state from the Athenian alliance. In course of a speech pleading for leniency, the Athenian speaker Diodotus claims that 'At the present time the common people (dèmos) of all the cities is well disposed to you, and either does not join with the aristocrats (oligoi) in revolting, or, if forced to do so, is hostile from the beginning to those who stirred up the revolt...' (3.47.2) Now, as pointed out in Robinson 2001a, one cannot take this statement at face value: unlike the previous quotations, which produce Thucydides' own words as commentator on events, this one comes as part of a speech he attributes to one participant in a heated debate in the Athenian assembly, who obviously puts a self-serving spin on events. Nevertheless, his comment still constitutes evidence that contemporary Athenians might have believed, or could have been persuaded, that the class of people (the dèmos) most supportive of democracy in cities within their imperial alliance preferred to side with democratic Athens rather than aristocratic factions within their own states.

But perhaps most telling of all is the sequence of events Thucydides describes in the fifth book of his history as he narrates the formation of a new military alliance in the Peloponnese designed to rival that of Sparta. After Sparta agreed to peace with Athens in $421 \mathrm{BC}$, angering a number of Sparta's allies, one of them (Corinth) 
initiated diplomatic efforts to build a new Peloponnesian alliance around Sparta's longtime adversary Argos, which had been neutral in the war with Athens. The story of the negotiations, diplomatic maneuvering, and, ultimately, warfare that followed this initiative is spelled out in great detail by Thucydides, and we need not work through it all. The aspect to note here is one rarely emphasized: the importance of constitutional type - particularly democracy - in shaping events. Argos, a thoroughgoing democracy in this period, ${ }^{9}$ eagerly embraced Corinth's initiative in order to feed its hegemonic ambitions. But right from the start the Corinthian ambassadors who hatched the idea were worried about letting the Argive people (dèmos) do the negotiating with potential allies, and so insisted that it empower a select committee to handle matters (5.28.1). Aside from the desire to keep things more secret via the committee (which Thucydides specifies as the reason offered by the Corinthians, 5.27.2), Corinth, an oligarchy, may have also hoped that by keeping the masses of ordinary Argives out of the negotiation process it could mitigate the democratic profile of its new alliance. If so, it was to be disappointed. The first state to join up was Mantinea, and among the reasons Thucydides gives for their decision was that the Argives were 'democratically governed like themselves.' (5.29.1) Elis, almost certainly a democracy at this time, ${ }^{10}$ also joined (5.31.1). Other states wavered, including Boeotia and Megara. Why did they hesitate? According to Thucydides (5.31.6), it was because of the Argive democracy, which the oligarchic Boeotians and Megarians worried would suit them less well than the conservative order of their present allies, the Spartans. Eventually, for various reasons, oligarchic Corinth itself would abandon, and democratic Athens join, the alliance, underscoring its democratic character. Argos welcomed the Athenians, in part, Thucydides tells us, because of their common democratic system of government (5.44). In the end, Argos' 
Peloponnesian power play suffered defeat at the battle of Mantinea in 418 - which was immediately followed by Sparta's fomenting of the oligarchic coup at Argos. The resulting non-democratic government failed to last, but the attempt itself further illustrates the degree to which Argos' democracy was seen by its foes as driving its foreign policy. And indeed, when demokratia reasserted itself at Argos within a few months, the state joined again in alliance with democratic Athens and pursued an antiSpartan policy.

This sequence of events, combined with the other Thucydidean passages singled out here (and a few more not noted above), ${ }^{11}$ is revealing. Clearly, a rivalry existed between oligarchic and democratic governments at this time. Aristocratic leaders of conservative constitutional orders distrusted democratic states. Democratic decision-makers paid attention as well, more readily joining other democratic states in alliance. And outside powers of either variety did not hesitate to capitalize on preexisting internal divisions within a given state to foment a democratic or oligarchic revolution in that state consonant with the constitutional alignment of the outside power. The polarization is striking, and would seem to provide a good foundation for ancient democratic peace.

However, as already discussed, such a peace never materialized. Democracies found themselves fighting each other now and again, as, for example, Argos did in the years following its alliance with Athens when it sent troops to support the Athenian expedition against democratic Syracuse. Any cooperation among democracies is subordinated, it would seem, to more pressing goals. Indeed, it must be emphasized that Thucydides himself never raises populist fellow-feeling as a spur to war or peace in this era, despite the democratic/oligarchic polarization in Greece upon which he occasionally comments. His narration of the events in book 5 , with all the diplomatic 
and strategic maneuvering leading up to the new coalition around Argos, stresses the same kinds of motives and factors that he highlights elsewhere in his history as leading to clashes: fear of loss of prestige and power (Sparta's great concern, should its Peloponnesian league be eclipsed by an Argive one [5.30; see also 1.23, 88]); the need to gain advantage before the coming of an inevitable war $(5.28,44$; also 1.44$)$ hegemonic ambition $(5.28$; also $1.67-8,6.1)$; territorial disputes with neighbors $(5.29$, 31, 41; also 1.39); past wrongs and services (5.31, 44; also 1.25-6, 32, 40). The democratic connections I have highlighted take some noticing: Thucydides never himself draws attention to the democratic profile of the alliance that emerges.

For the sake of comparison, let us briefly consider another ancient author, Xenophon, whose history of Greece picks up where Thucydides' war account ends and then continues to cover Greek events for a few decades after the end of the Peloponnesian War. While it is apparent from Xenophon's descriptions that the polarization of democratic and oligarchic states continued and remained a factor in fueling a number of wars and revolutions of the early fourth century, he too prefers to stress other factors in explaining why fighting broke out or persisted, to include the desire for state freedom and autonomy, the chances of winning or losing, past injuries, past loyalty or services, or Greek unity in opposing non-Greeks. ${ }^{12}$ Often, he is surprisingly vague about governmental change or constitutional factors in describing the outcomes of wars when one state conquers another. ${ }^{13}$ Given that he certainly was aware of the continuing democratic/oligarchic polarization, it is worth noting that he, like Thucydides, seemed to think it less important a factor for bringing about war or peace than other motivating forces.

The conclusion that one should draw from all this ancient testimony is that contemporary Greek observers certainly understood that tensions between competing 
democratic and oligarchic models of polis governance frequently spilled over into the realm of war, civil strife, and alliance-making in the fifth and fourth centuries. Nevertheless, the observers did not recognize anything like a true democratic peace ever taking hold (and, as my previous article showed, none ever did). States of a given political alignment might keep in mind how they could use factional allegiances to their advantage when competing with rival states, of course. Indeed, one could almost speak of 'democratic war' — that is, wars democracies waged purposely targeting oligarchies (and 'oligarchic war' when the reverse happens) — as democracies and democratic factions not infrequently cooperated in conflicts against oligarchies and oligarchic factions and vice versa. Leaders of populist factions would attempt to capitalize on this habit so as to gain allies for their internal struggles. Thus, even though the ancient authors rarely highlighted it, a degree of fellow-feeling or at least consciousness of convergent interests must have existed between democratic states and factions. Why, then, did no observable democratic peace emerge?

\section{AFFINITIES WITHOUT PEACE: AN EXPLANATION}

First of all, one must acknowledge the role of the democratic-oligarchic dynamic itself. Whatever cooperation between democracies existed did not exist in isolation: it went hand-in-hand with a comparable affinity between oligarchies in circumstances of violent competition between the two, competition that itself formed part of the larger conflict between great powers (Athens and Sparta primarily, but at times with the participation of Thebes and Argos). Thus any explanation for why there was no democratic peace to match the observed 'democratic war' should not, ideally, rely entirely on theories about the internal practices of democracy. The 
consideration, for example, of the factors most often discussed in explaining the appearance of democratic peace in other eras - the institutional restraints and cultural norms of democracies, shared experiences of democratic leaders, etc. - can only offer a partial answer. ${ }^{14}$

A key aspect of ancient democratic behavior that may help us toward an explanation comes out of Thucydides' history — or rather, it is something that, strikingly, does not come out. One would search in vain in Thucydides for evidence of a conviction among Greek democrats that democracy should be promoted for its own sake. That is, one detects no sense of mission in ancient democracies that we read of in Thucydides (or in other ancient texts) to spread the gospel, as it were, so more Greeks could enjoy the benefits that the democratically governed felt themselves. ${ }^{15}$ Its absence is particularly striking in Thucydides' report of Pericles' funeral oration, probably the most famous encomium to a democratic government from all of antiquity: Pericles heaps praise on Athens for (among other things) its constitution, claiming that it was a more a model (paradeigma) for others than it was copied from others (2.37.1), but nowhere suggests that Athens had — or should have — striven to promote it abroad. Nor does any hint of such a sentiment appear elsewhere in Thucydides' history or others'. The contrast with the modern world, or at least the modern United States, is striking. For decades now, it has been taken as a given that the U.S. seeks to promote democracy around the world (even if inconsistently, or at the point of a gun) as a basic tenet in its foreign policy. The recent broadcasting of this mission by the Bush administration in prominent speeches and policy statements only highlights a longstanding U.S. goal shared by both major political parties. ${ }^{16}$

The absence of a comparable messianic drive among ancient Greek democrats signals, one may suppose, a different conception of constitutional ideals and their 
importance within the polis setting. Just as no democratic city-state, however happy it may have been with its form of government, felt the need to promote the idea abroad for the sake of the idea, so no democratic city-state would automatically sympathize with — to the extent of avoiding hostilities with — a fellow democracy simply because of its democracy. Perhaps the Greeks believed that constitutional types had little to do with a citizen body's fundamental character, and it is the character of a people (combined with polis self-interest) to which Thucydidean speeches for or against war constantly appeal. ${ }^{17}$ After all, Greek city-state governments of all constitutional stripes were far smaller and far more directly connected to the people themselves than modern states with all their governmental apparatus. ${ }^{18}$ Thus the major factors we hear of for going to war in Thucydides (such as land disputes or past injuries or hegemonic ambitions) seemed far more immediate and illustrative of a neighboring population's threat or worth than the manner of internal procedures it may have used to decide to act the way it did. To be sure, the decision-makers of states of one constitutional type seem to have found it easier to work with or trust those in a similar political milieu when considering alliances: democratic politicians or indeed the ruling dèmos itself in a democracy would have no qualms about conducting business with their equivalent in another democracy, whereas (the book 5 evidence from Thucydides seems to show) there was a deficit of such ready trust on the part of oligarchic leaders in making deals with popularly ruled city-states. But a systemic affinity among democratic actors, lacking any larger dedication to the ideal of democracy across Greece, could not trump the more immediate imperatives (potential threat, past injury, polis character, sworn alliances, etc.) that led the small, locally oriented Greek communities to make war on one another. ${ }^{19}$ 
The absence of devotion to abstract constitutional principle — or perhaps, more precisely, the inability of any such attachment to overcome the intensely local perspective of the Greek polis - would help explain how it is that, in Thucydides' accounts, internal democratic/oligarchic struggles can have such a prominent place in the prosecution of wars and yet get so little explicit play in discussions of causes. Recall in the passages from book 3 noted earlier in this paper how Thucydides qualifies the importance of factional struggles in the Corcyrean civil war: it took the existence of the larger war between Athens and Sparta to spark these vicious internal conflicts in the first place; and even once they broke out, the alleged agendas of the participants (democracy or oligarchy, expressed via whatever specious slogans they might use) mattered little, for the truth was that winning personal power in their local community motivated them, not allegiance to higher constitutional ideals.

A lesser degree of attachment to political causes beyond the arena of the polis would also explain how it was that interstate democratic connections - which clearly did exist — were ignored so often when faced with the prospect of war. Perhaps the most dramatic illustration is the episode leading most directly to the Peloponnesian War itself: the conflict between Epidamnus, Corcyra, and Corinth, described by Thucydides in book 1. The troubles began when the dèmos of Epidamnus, hardpressed by recently exiled aristocrats (hoi dunatoi), made an appeal for help to its mother-city, democratic Corcyra. Corcyra refused to help, preferring to side with the aristocrats. The desperate Epidamnians next turned not to some other democracy, but to oligarchic Corinth, which like Corcyra was tied by kinship to Epidamnus as a (secondary) mother-city. The Corinthians, with a longstanding grudge against their former dependents the Corcyreans, agreed to help the Epidamnian dèmos, the Corinthians' oligarchic system apparently offering no impediment. Finally, 
democratic Corcyra then went to war against the demos of Epidamnus. Throughout this buildup to open international conflict, we find the appeal across state lines of shared constitutional ideals utterly trumped by the more vivid feelings of polis anger at past wrongs, desire for territorial control, and ties of kinship. These, of course, are the kinds of factors that Thucydides highlights as motivators not just in this account but throughout his history.

The hypothesis that democratic peace failed in Greece because of a different Greek valuation of constitutional ideals, one that inhibited attachment to constitutional causes beyond one's own polis, makes good sense of the testimony in Thucydides (and other, less rich sources from antiquity). But further factors may also have played a role in preventing the emergence of an ancient democratic peace, such the differing political institutions of ancient and modern democracy. These will be considered in Russett's article later in this issue. ${ }^{20}$

Author's note: I wish to thank the participants in the PRIO conference at Columbia University and the anonymous readers for $J M E$ for their comments on earlier versions of this paper.

\section{Notes}

\footnotetext{
${ }^{1}$ The full security strategy statement (from September 2002) is available from the White House at http://www.whitehouse.gov/nsc/nss.html. It is also archived as: U.S. Executive Office of the President. The National security strategy of the United States of America. Washington. September 2002, available at GPO Access: http://purl.access.gpo.gov/GPO/LPS22467 (retrieved July 18, 2005).

${ }^{2}$ The text of this press conference (and other occasions since on which the President voiced similar themes) is available from the White House at http://www.whitehouse.gov/news/ (Accessed December 16, 2005). See also Secretary
} 
of State Condoleezza Rice's recent editorial on democratic peace in the Washington Post (Rice 2005).

${ }^{3}$ A joint study from the Chicago Council on Foreign Relations and the Program on International Policy Attitudes released in September 29, 2005, suggests that, despite the President's words, Americans at large are skeptical of the notions that democracies make the world safer or are less likely to go to war with one another. Full text of the study, 'Americans on Promoting Democracy', is available at www.pipa.org and www.ccfr.org. (Accessed December 16, 2005). For doubts about democratization and peace in Iraq and the Middle East, see Mansfield \& Snyder 2005. ${ }^{4}$ See bibliography listed in Robinson 2001a. Realist skeptics of democratic peace received a boost with the publication of Gowa 2000, though compelling studies treating the modern phenomenon as both empirically valid and worthy of exploration continue to appear, e.g. Kadera et al. 2003.

${ }^{5}$ Though one does not have to read Thucydides as a die-hard realist. See, for example, the interpretation offered by Richard Ned Lebow in his contribution to this volume. ${ }^{6}$ See Weart's response to my article (Weart 2001) and my following note (Robinson 2001b). For further examples of ancient inter-democratic conflict that would seem to violate the theorized peace, see Hansen in Hansen \& Nielsen 2004: 84-5. On the incompatibility of democratic peace theory to the case of ancient Athens in particular, see Mitchell 2003.

${ }^{7}$ Loeb translation (Smith 1920), slightly modified. There are some grammatical difficulties with the second sentence of the first quotation, especially as regards the phrase 'nor any inclination to do so' (oude hetoimōn) - there may be a manuscript error here, rendering the text uncertain. See Gomme et al. 1945-81: 2.372-3 and Hornblower 1991-1996: 1.480-481.

${ }^{8}$ E.g., Ps-Xenophon ('Old Oligarch') 1.14, 16, 3.10-11; Aristotle, Politics 1307b; Thucydides himself again at 1.19.

${ }^{9}$ Leppin 1999; Robinson (in preparation).

${ }^{10}$ Roy in Hansen \& Nielsen 2004: 497; Robinson (in preparation).

${ }^{11}$ E.g., during the brief oligarchic revolution at Athens in the years 411-410, Thucydides tells us that Athenian oligarchs went about changing democratic governments in the empire into oligarchies (8.64-5), and we know that the restored Athenian democracy returned popular governments to some of these at least (Paros: Diodorus Siculus 13.47.8). Thucydides also notes that Sparta ensured the loyalty of its allies by installing oligarchic governments $(1.19,126)$.

${ }^{12}$ E.g., on freedom and autonomy (eleutheria/autonomia): 3.1.3, 20; 3.4.5, 25; 4.1 .35 eleutheria $=$ no foreign ruler; 4.8.14).

${ }^{13}$ E.g., the description of Sparta's war on Elis of c. 401, which downplays obvious democratic/oligarchic tensions in the causes and course of the war (3.2.21-31), or the stasis in Corinth of c. 492, for which he never actually admits that democracy resulted or that populist politicians had been pushing for it all along (4.4.1-8; cf. Diodorus Siculus 14.86.1, Oxyrhynchus Historian 2.2-3), or the emphasis on non-factional causes of Sparta's attack on Mantinea in 386 (5.2.1-3).

There are exceptions, however - occasions where his text is unambiguous that democratic/oligarchic politics played roles in wars and alliances, including 4.8.20 (Rhodes); 5.2.3-7 (the result of the Spartan/Mantinean war); 5.2.25ff. (Theban stasis); 7.1.42-3 (Achaia); 7.1.44 (Sicyon).

${ }^{14}$ My thanks to Nino Luraghi for thoughts on 'democratic war' and the democraticoligarchic symmetry. Weart $(1998,2001)$ considers the similar oligarchic behaviors to 
be very significant as well, but unfortunately assumes, on little evidence, that it amounted to an 'oligarchic peace'. Cf. Robinson 2001b.

15 That this is true in Thucydides is significant, given his alertness to the dynamics of democratic/oligarchic competition. But it can also be said of ancient literature more generally: I am aware of no ancient text in which one can find statements suggesting a desire to spread democracy in Greece for its own sake. Always the motivation for fomenting revolution abroad or supporting a faction in another city seems to be the advantage that such would bring to the home state in terms of influence or war or alliance. See, for example, Ps.-Xen. 1.14, 16, 3.10-11.

${ }^{16}$ See text and notes at the start of this paper for the zeal of the Bush White House. For a similarly strident statement of the American imperative to spread democracy from the opposing political party in the U.S., see the comments of Bush's recent Presidential rival John Kerry in "Promoting Democracy, Human Rights, Development \& Rule Of Law" (retrieved October 1, 2004 from http://www.johnkerry.com/issues/national_security/democracy.html; archived at http://www.globalsecurity.org/military/library/report/2004/kerry natl-securityplans democracy.htm, retrieved July 18, 2005).

${ }^{17}$ E.g., Corinth and Corcyra in the debate at Athens (emphasizing the Corcyrean and Corinthian characters), 1.32-43; Corinth, Athens, and the Spartan ephor in the debate in Sparta (about the Athenian character), 1.68-79, 86; Cleon in the Mytilenean debate (about the Mytileneans), 3.37-40; Alcibiades in the debate before the launching of the Sicilian expedition (about the Sicilians), 6.17.

${ }^{18}$ Typical polis citizen populations ranged in the hundreds or low thousands for all but the largest states. Compare Ruschenbusch 1985 with specific results in Hansen \& Nielsen 2004.

${ }^{19}$ It is worth emphasizing here that the apparent Greek failure to prioritize broad, panHellenic democratic ideals over local considerations of interest need not indicate any lesser Greek attachment to democratic ideals within their own polis. As noted earlier in the paper, a strong allegiance to strikingly similar democratic principles as are practiced in the modern world (freedom, equality) characterize ancient democracies: the evidence from antiquity does not suggest that within the Greek polis internal democratic ideals were somehow undervalued.

\section{References}

Gomme, A. W., Andrewes, A. \& Dover, K. (1945-1981) A Historical Commentary on Thucydides, 5 vols (Oxford: Oxford University Press).

Hansen M. H. \& Nielsen, T. H. (Eds) (2004) An Inventory of Archaic and Classical Poleis (Oxford: Oxford University Press).

Hornblower, S. (1991-1996) A Commentary on Thucydides, 2 vols (Oxford: Oxford University Press).

Kadera, K. M., Crescenzi M. J. C., \& Shannon, M. L. (2003) Democratic Survival, Peace, and War in the International System, American Journal of Political Science, 47(2), pp. 234-247.

Leppin, H. (1999) Argos. Eine griechische Demokratie des fünften Jahrhunderts v. Chr., Ktema, 24, pp. 297-312.

Mansfield, E. D. \& J. Snyder (2005) Electing to Fight: Why Emerging Democracies Go to War (Cambridge, MA: MIT Press). 
Mitchell, R. (2003) Never at Peace: The Impact of War on the Emerging Athenian Democracy, Master of Liberal Arts thesis, Harvard University Extension School, Harvard University, Cambridge, MA.

Pope, M., 1988. Thucydides and Democracy, Historia, 37, pp. 276-296.

Rice, C. (2005) The Promise of Democratic Peace. Why Promoting Freedom Is the Only Realistic Path to Security [Op-ed, December 11] The Washington Post, p. B07.

Robinson, E. (2000) Democracy in Syracuse, 466-412 BC, Harvard Studies in Classical Philology, 100 (2000 [2001]), pp. 189-205.

Robinson, E. (2001a) Reading and Misreading the Ancient Evidence for Democratic Peace, Journal of Peace Research, 38(5), pp. 593-608.

Robinson, E. (2001b) Response to Spencer Weart, Journal of Peace Research, 38(5), pp. 615-617.

Robinson, E. (in preparation) Democracy Beyond Athens: Popular Government in the Greek Classical Age (Cambridge: Cambridge University Press).

Ruschenbusch, E. (1985) Die Zahl der griechischen Staaten und Arealgrösse und Bürgerzahl der 'Normalpolis', Zeitschrift für Papyrologie und Epigraphik, 59, pp. 253-263.

Russett, B. \& Antholis, W. (1992) Do Democracies Fight Each Other? Evidence from the Peloponnesian War, Journal of Peace Research 29(4), pp. 415-434.

Russett, B. \& Antholis, W. (1993) The Imperfect Democratic Peace of Ancient Greece, in: B. Russett Grasping the Democratic Peace, pp. 43-71 (Princeton, NJ: Princeton University Press).

Smith, C. F. (1920) Thucydides, 4 vols (Cambridge, MA: Harvard University Press).

Weart, S. (1998) Never At War: Why Democracies Will Not Fight One Another (New Haven, CT: Yale University Press).

Weart, S. (2001) Remarks on the Ancient Evidence for Democratic Peace, Journal of Peace Research, 38(5), pp. 609-614.

Eric Robinson, b. 1964, PhD in Ancient History (University of Pennsylvania, 1994); Associate Professor of History at Indiana University (2006-). Publications on topics primarily in ancient Greek history include the books The First Democracies: Early Popular Government Outside Athens (Franz Steiner Verlag, 1997) and Ancient Greek Democracy: Readings and Sources (Blackwell, 2003). 